\title{
An Analysis on Policy Direction of Community Based Management of Mangorove Ecosystem in Sungai Pisang Bungus Teluk Kabung District in Padang City
}

\author{
Guni Refinda \\ Graduate Student of Geography Education Program \\ Faculty of Social Science Universitas Negeri Padang, INDONESIA \\ Email: gunirefinda@gmail.com
}

\begin{abstract}
This research was motivated by lack of understanding and public awareness in the management of mangrove ecosystem. This was due to the community lack of knowledge on how to take advantage of mangroves in coastal and tidal areas. The purpose of this study was to know the community Participation, Strategy of Mangrove Management and to formulate appropriate policies of CBM based mangrove management. This research was a mixed method research or a combination of quantitative and qualitative research. Research findings indicated that the participation of Sungai Pisang Community in managing the mangrove ecosystem had not gone well and the students were nor aware of mangrove management. By using the aspect of Mangrove management such as the aspect of strength, threat. Weaknesses, and opportunities, 9 strategies were formulated, namely: (1) Local rules about Mangrove ecosystem management need to be written, (2) CMB-based Mangrove nurseries program, (3) Performing preventive action by approaching and developing local people awareness of appropriate technology for Mangrove area, which is also called Silvofishery. (4) Giving strict punishment to the people who were destroying mangroves for private purposes, (5) Optimization and rehabilitation of vacant land into a mangrove forest, (6) Returning the local wisdom in managing coastal areas, (7) Following counseling and training on mangrove management, (8) Improving supervision and monitoring, (9) Dividing the duties, functions and responsibilities of stakeholders according to their expertise. Based on those strategies, policy priorities were formulated. They are: are(1) Following the counseling and training on mangrove management, (2) Optimizing and rehabilitatingthe vacant land into a mangrove forest, (3) Increasing supervision and monitoring, (4) returning local wisdom in coastal area.
\end{abstract}

Keywords : Management, mangrove Ecosystem, Community Based Management (CBM).

\section{Introduction}

One of important aspect of Indonesian as an archipelagic country is its coastal areas. Coastal area is an interface area existing between land ecosystem and marine ecosystem which has unique characteristic and contains higher biological production and serve other enviromental services. Natural resources of the area can attract some people to directly take advantage or regulate its utilization because it gives additional income to economic sectors. Economic sectors of coastal area utilization can be in form of mines, fishery, forestry, industry, tourism and others. Coastal area is a transitional ecosystem which is influenced by land and sea. One of coastal ecosystem is mangrove ecosystem. Mangrove ecosystem plays a role as balancer of coastal ecosystem and marine ecosystem. the benefits of mangrove forest are providing nutrient for aquatic biota, as nursery ground for coastal and marine biota, to prevent coastal abrasion, hurricane and tsunami, waste absorbent, preventing sea water intrusion, and mangrove forest also have economic benefit such as lodging provider, medicines, tools and fishing (Rahmawaty, 2006). 
Lately, coastal ecosystem such as mangrove ecosystem, coral reef, and estuary has been decreasing. The most abundant ecosystem is mangrove ecosystem which is caused by human activities. the acticities are mangrove lodging, the existence of pond area, rapid development of coastal area. Indonesia is a largest mangrove ecosystem area in the world with an area of 19\% of World's Mangrove forest, 10\% more than australia's and 7\% more than Brazil's. However, mangrove forest in Indonesia has been decreasing every year. Forestry Department in 1999/2000; Kamal et al., (2003) informed that there are about 9.2 millio hectares of Mangrove forest in Indonesia and 5.3 million hectares of damaged mangrove forest or about $57.6 \%$ of mangrove areas in Indonesia.

Sungai Pisang which has an area of 914 hectares, is a coastal area located in Bungus teluk Kabung District in Padang City. The northern area is boarded by Sub-district of North teluk Kabung, the Eastern area is boarded by Siguntus Village of South Pesisir Regency, the southern area is boarded by Sungai Pinang Village of South Pesisir Regency, and the western Village is boarded by Indian Ocean. This place is located in coastal and hilly area and has a height of 2 meters above the sea level. It has $15 \mathrm{~km}$ coastline and has $7 \mathrm{~km}$ distance from district centre and $32 \mathrm{~km}$ distance from the centre of Padang City. Coral reef ecosystem can be found in almost all islands in Sungai Pinang. Coral reef is a habitat for marine ecosystem that has econimic potential. Along the coastline of Sungai Pisang was grown by mangrove forest which is decreasing every year. Empirical data showed that in 1970s there was 90 hectares of mangrove forest in Sungai Pinang and only 20 hectares in 1996 (DKP Kota Padang, 2001). The area of Sungai Pisang includes a group of islands that surrounds the area which are named after local legends such as Pasumpahan Island, Sirandah Island, Sikuai Island, Sironjong Island, Pagang Island and Setan Island. Furthermore, according to Mangrove and Coastal Study Center and Faculty of Fishery and Marine Science og Bung Hatta University (1998), the wide of mangrove forest in Padang City is about 120 hectares. Especially in Sungai Pisang, the wide is 20 hectares. Meanwhile, according to Hermalena's study (2005) the wide of mangrove forest in Sungai Pinang is 25 hectares. While according to Lurah's office of Teluk Kabung Selatan (Sugai Pisang), in 2015 the wide of mangrove forest is 35 hectares with the height of 2-10 meter. Generally, there is only 1 mangrove species found in sungai Pisang's mangrove forest, namely Xylocarpus granatum. Moreover, Sungai Pisang also has various fauna especially bird and there are about 29 species and family of birds found in Sungai Pisang. After observing the area, damage was found some group of mangrove ecosystem. The damage was caused by community's lack of understanding about the function and benefit of mangrove forest for the coastal area. The forest is cut down only for the sake of personal economy, charcoal industry, fishponds, residential area, port, plantation, shipbuilding materials and others. It results in the ecological imbalance. To solve this problem, a good management of mangrove forest utilization is very important for the sake of sustainability of natural resources.

\section{Method}

The researcher was conducting a mixed method research. according to Sugiyono (2011) mixed method research is a research method that combine quantitative and qualitative method to realize the purpose of the research. Quantitatively, the data was analyzed to know its consostency ratio for formulating the policy of mangrove forest management. This type of analysis is also nown as AHP analysis. Qualitatively, the data of this research was analyzed by using SWOT analysis in order to found the strategies of mangrove forest management. The data from AHP will be supported by SWOT data and vice versa. The combination of SWOT and AHPalso eased the researcher to determine the priorities of mangrove managemet strategies. Factors and Alternatives in SWOT was based on the data obtained from interview with the respondent. The data obtained from the field was analyzed descanalyze the strength, weakness, opportunity and threats of mangrove management. SWOT analysis is based on the logic of maximizing strength and opportunities and 
minimizing weakness and threats. The process of determining the strategies was related to the development of mission, goal, strategy, and policy. Therefore, a strategic planner should analyze the factors of strategies (strength, weaness, opportunity, and threat) in the present time and condition which is also known as situation analysis. Most used situation analysis technique is SWOT (Rangkuti, 2006).

\section{Result and Discussion}

Management is a key to conserve coastal area resources, in this case threatened mangrove forest. Exessive utilization of coastal resources could damage the ecosystem and should be stoped. Physically, coastal area plays a role as stabilizer of land ecosystem. The damage of coastal area will badly impact the resources and the quality of environment as a whole. To manage mangrove ecosystem, it was important for the researcher to collect the data in the field for deciding the management strategies. This data contained internal and external factor of the research object. To collect this data, the reseacher used observation and interview on some stakehoder for example local people, governement, and non-governemental organization.

The formulation of management policy strategy of mangrove ecosystem will determine the direction and the purpose of utilization planning and development of mangrove ecosystem. Management strategy of mangrove ecosystem needed to analyzed multidimensionally by considering all related aspects of mangrove management planning.

The hierarchy of Policy Direction of Mangrove ecosystem management is arranged based on three criteria, namely participation, management, and strategy. These criteria were adjusted with SWOT analysis. the result suggested that CMBM based mangrive ecosystem management can be implemented by regarding community participation, environmental management in this case mangrove management.

The criteria determine the policy alternatives of CBM based mangrove ecosystem management. the alternatives are:

1. Local written rules of mangrove ecosystem management

2. CMB based mangrove nursery program.

3. Preventing mangrove forest exploitation through approaching and raising land owner's awareness about proper technology for fishponds in mangrove area (Silvofishery)

4. Giving strict punishment to the people who damage the ecosystem for personal reason

5. optimalizing rehabilitation activities of vacant land for mangrove forest.

6. Restoring local wisdom in managing mangrove ecosystem

7. participating in training and counseling about mangrove forest management

8. improving supervision and monitoring

9. giving tasks, functions, and authorities to the stakeholders based their area of expertise.

After creating a hierarchy framework, then the alternatives was scored. Scoringis based on the AHP assessment criteria formulated (Saaty in Sismantoro, 2012). Comparative comparison values are processed by using Expert Choise version 3.0 program to rank all the alternatives. A consistent Policy priority should have consistency ratio value of $<0,1$. From the table above we can be seen the nature of the consistency ratio of policy alternatives that have been prepared, then by using AHP analysis consistency ratio value obtained is 0.016 or is $<0.1$. This means that criteria with various alternatives that have been prepared are consistent so that it can be continued to setting policy priorities. Of the three criteria related to the management of mangrove ecosystems in the Sungai Pisang, the criteria of community participation is more critical than strategy with score 3 , management is slightly more important than strategy with score 2 and management is as important as participation with score 1 .

Policy priorities of mangrove ecosystem management in Sungai Pisang were determined based on eigain value of every policy alternative. There are 4 alternatives that have high eigain value. This alternatives 
are made into policy priorities in managing mangrove ecosystem in Sungai Pinang, Bungus Teluk Kabung District. They are:

1. Participating in Training and Counseling about mangrove Management $(0,900)$

2. Optimalizing the rehabilitation of vacant land into mangrove forest $(0,783)$

3. Improving supervision and monitorig $(0,717)$

4. Restoring the local wisdom in Mangrove management $(0,700)$

\section{Conclusion}

SWOT analysis on mangrove management strategies, there were 9 strategies that can be used in managing mangrove forest. Based on the formulation of strategies based on criteria of participation, mangrove ecosystem management and management strategies, there are four policy priorities suggested in this research, namely 1) Participating in Training and Counseling about mangrove Management; 2) Optimalizing the Rehabilitation of vacant land into mangrove forest; 3) Improving supervision and monitorig; and 4) Restoring the local wisdom in Mangrove management.

\section{References}

Bengen. (2001). Pedoman Teknis Pengenalan dan Pengelolaan Ekosistem Mangrove. Bogor : Pusat Kajian SumberDaya Pesisir dan Lautan Institut Pertanian Bogor

BPS Kota Padang (2014). Bungus Teluk Kabung dalam angka 2014. Padang

COREMAP-LIPI. (1997). Petunjuk Pelaksanaan Pengelolaan Berbasis Masyarakat. Dokumen buah kerjasama antara Lembaga Ilmu Pengetahuan Indonesia, Pusat Penelitian dan Pengembangan Oseanologi, Proyek Rehabilitasi dan Pengelolaan Terumbu Karang dan PT. Ecolink Utama. 19 hal.

Dahuri, R. Rais, J., Ginting, S.P., dan Sitepu, M.J. (2001). Pengelolaan Sumberdaya Wilayah Pesisir dan Lautan secara Terpadu. Cetakan Kedua : ISBN 979-408-381-X. PT. Pradnya paramita, Jakarta. 328 hal.

Fandeli, C, dan Muhklison (2000). Pengusahaan Ekowisata. Fakultas Kehutanan. Yogyakarta: Universitas Gadjah Mada.

Farawangsyah, (2013). Partisipasi Masyarakat Dalam Pengelolaan Ekosistem Mangrove di Kelurahan Tekolabbua Kecamatan Pangkajene Kabupaten Pangkep. Fakultas Kehutanan Makassar : Universitas Hasanudin.

Guswardi (2008). Analisis Tingkat Partisipasi Masyarakat dalam Pengelolaan Hutan Mangrove (Studi Kasus : di Sungai Pisang Kecamatan Bungus Teluk Kabung Kota Padang)

Hermalena, L. (2005). Keanekaragaman Burung Yang Terdapat di Sekitar Hutan Mangrove Daratan Pesisir Kota Padang. jurnal Mangrove dan Pesisir Vol. V. No. 1/2005. Pusat Kajian Mangrove dan Kawasan Pesisir Universitas Bung Hatta.

Kamal, Eni dan Suardi, ML. (2002). Pengelolaan Ekosistem Pesisir dan Lautan Propinsi Sumatera Barat. Warta Mangrove dan Pesisir No.2/Thn.II/2002.HL.1-9

Keraf, Sonny. (2002). Etika Lingkungan. Jakarta [ID]: PT Kompas Media Nusantara. 322 hal

Kusworo, HA (2000). Pengembangan Wisata Pedesaan Tepi Hutan Berbasis Kerakyatan dalam Pengusahaan Ekowisata, Pengusahaan Ekowisata. Chafid Fandeli, ed. Fakultas kehutanan. Yogyakarta: Universitas Gadjah Mada.

Lasibani, Suardi M. (2010). "Pengelolaan mangrove berbasis masyarakat di Jorong Mandiangin Kabupaten Pasaman Barat”. Tesis Pasca sarjana Universitas Bung Hatta Padang. 2010 